\title{
The battle of numbers: Refugee protection, race, and Neoliberal politics of bureaucratic efficiency
}

OÑATI SOCIO-LegAl SERIES Volume 10, IsSue 6 (2020), 1084-1106: GOVERNING THE POLITICAL: LAW AND THE POLITICS OF RESISTANCE

DOI LINK: HTTPS://DOI.ORG/10.35295/OSLS.IISL/0000-0000-0000-1047

RECEIVED 23 July 2018, ACCEPTED 08 FEBRUARY 2019

\section{AZAR MASOUMI*}

\section{Abstract}

This paper examines the early years of systematic refugee claim processing in Canada to explore the ways neoliberal bureaucratic practices rely on and (re)produce racialization in their day to day operations. I argue that due to the rise of neoliberalism, systematic refugee protection in Canada has come to exclude claimants who have borne the label of economic migrant. Furthermore, I argue that the exclusion of economic migrants from refugee protection has been a racialized and racializing project. The institutional procedures that worked to exclude these migrants inherited, drew upon, and reproduced racialized knowledges about certain national groupings. Racialization of economic migrants provided the claim processing bureaucracy with quick and efficient means of screening large numbers of claimants out of their workload. Thus, I argue that neoliberal governance of refugee claims in Canada has been a racialized and racializing bureaucratic practice.

\section{Key words}

Law and bureaucracies; race and racialization; Neoliberal governance

\section{Resumen}

El artículo examina los primeros años de proceso sistemático de solicitudes de asilo en Canadá para explorar la forma en que las prácticas burocráticas neoliberales se apoyan en, y (re)producen, la racialización en sus actividades cotidianas. Argumento que, debido al auge del neoliberalismo, la protección sistemática a los refugiados en Canadá ha terminado excluyendo a solicitantes que llevan la etiqueta de migrantes económicos, y que la exclusión de los migrantes económicos de la protección a los refugiados ha sido un proyecto racializado y racializante. Los procedimientos institucionales que han servido para excluir a dichos migrantes heredan conocimiento racializado sobre determinados grupos nacionales. La racialización de los migrantes

\footnotetext{
* Azar Masoumi is a PhD Candidate in Sociology at York University, Toronto, Canada (ON M3J 1P3). Email address: amasoumi@yorku.ca.
} 
económicos ha proporcionado a la burocracia de procesamiento de solicitudes unos medios rápidos y eficaces de excluir a numerosos solicitantes del sistema. Por tanto, argumento que la gobernanza neoliberal de solicitudes de asilo en Canadá ha sido una práctica burocrática racializada y racializante.

Palabras clave

Derecho y burocracias; raza y racialización; gobernanza neoliberal 


\section{Table of contents}

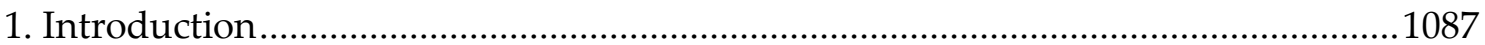

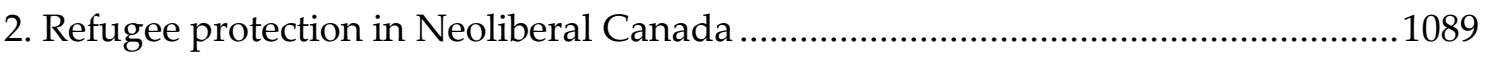

3. The Battle of Numbers: Bureaucracy against the economic migrant ........................1092

4. Locating economic migrants: Racialization and bureaucratic efficiency ..................1095

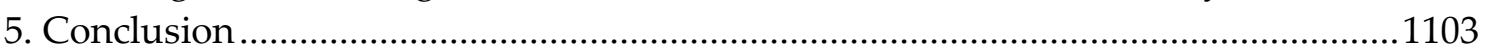

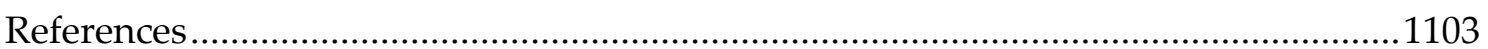

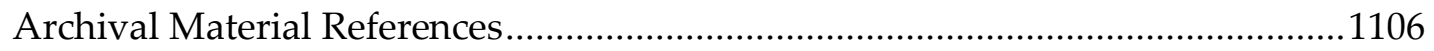




\section{Introduction}

On the eve of Immigration Act 1976 passing into Canadian law, the liberal immigration minister J.S.G. Cullen gave a speech that formulated the emerging neoliberal politics of refugee protection. After highlighting the unprecedented option of private refugee sponsorship in the new Act, Minister Cullen emphasized that economic hardship did not constitute a legitimate ground for receiving refugee protection:

We cannot open our borders to all economic refugees, such as citizens of third-world countries, and we can't do anybody a favor if we bring people to Canada who will not be able to establish themselves. (The Globe and Mail 1978, 8)

This paper reiterates, albeit in a critical and expansive way, the basic connections that Minister Cullen articulated between refugee protection, economic migrants, and neoliberal logics of immigration administration. As I will show, legislating a systematic, specialized, and innovative regime of refugee protection in Canada has come at the cost of excluding economic migrants: migrants who supposedly file refugee claims not to flee "real" persecution, but in hopes of economic gain. Further, I will demonstrate that excluding economic migrants from refugee protection has been a racialized project. From the outset of its operations, the Canadian refugee protection bureaucracy has relied on racialized formulations to label, isolate and reject large groups of claimants as economic migrants. These racialized formulations have allowed the bureaucracy to process large parts of its caseload quickly and at little cost. In other words, racialized exclusion of economic migrants contributed to efficient and cost-effective processing of refugee claims. Hence, I argue that racialization has been a key administrative tool in neoliberal governance of refugee claims in Canada.

A large body of scholarship has examined the relationship between racialization and neoliberalism. Scholars have examined the ways neoliberal ideology conceals the operations of racial injustice, by actively suppressing race as a legitimate topic of discussion (Omi and Winant 1994, Enck-Wanzer 2011), through the myth of meritocracy (Davis 2007), or individualized conceptions of choice (Giroux 2008), all the while that it reinforces racial inequality (Goldberg 2009) and engenders racialized subjectivities (Melamed 2006). Others have examined the racialized nature and effects of neoliberal policies, for instance in relation to resettled refugees (Ong 2003), the urban poor (Soss et al. 2011), temporary migrant workers (Sharma 2001), or unauthorized travellers (Andreas 1996).

While the existing scholarship explores the racialized and racializing aspects of neoliberal policy, ideology, and discourse, it rarely examines the ways neoliberal methods of governance are entangled with racialization in practice, particularly within bureaucracies and institutions. As a result, the existing scholarship overemphasizes the discursive nature of neoliberal racialization, and overlooks the material ways these discourses shape actual practices of governance.

This paper explores neoliberal racialization beyond its discursive effects and considers the ways neoliberal logics of governance, for instance the impetus to cut costs and do more with less, rely on racialized formulations and (re)produce racialized outcomes. In this sense, this paper takes up the call by Roberts and Mahtani (2010) to move beyond simply mapping the racialized effects of neoliberalism, and instead examines the ways 
neoliberalism "actively produces racialized bodies" (Roberts and Mahtani 2010, 248). By dissecting the co-reliant and co-constitutive relationship between racialization of economic migrants and neoliberal governance of refugee protection, I respond to Roberts and Mahtani and explore the ways racialization is "inextricably embedded in the neoliberal project" (Roberts and Mahtani 2010, 250). I show that racialization is not simply a side-effect of neoliberal discourse, but central to its day to day and practical operations.

Delineating the racialized and racializing mechanisms of neoliberal governance requires attention to both the neoliberal break from and continuation of liberal structures of (racialized) power. Neoliberalism, as Wendy Brown has suggested, is "a peculiar form of reason that configures all aspects of existence in economic terms", and one that converts "the distinctly political character, meaning, and operation of democracy's constituent elements into economic ones" (Brown 2015, 17). In this sense, as Brown also notes, neoliberalism is distinct from liberalism in its unabashed abandonment of the political promise of universal equality, however perpetually unfulfilled, in favour of economically motivated logics, rationalities, and calculations. It is in this vein, for instance, that the basic equality-inducing protections provided by the welfare state are withheld and socio-political inequalities widen. In the context of refugee protection, as I will show, the rise of "'economization' of political life" (Brown 2015, 17) prioritizes fast, efficient, and cost-effective bureaucratic processing of refugee claims, over and beyond humanitarian concerns or even symbolic gestures to the ideal of universal equality.

Nonetheless, as post-colonial scholarship has long suggested, the racialized and racializing effects of neoliberal power are only the continuation of long-standing racial histories of liberalism itself. As I will show in this paper, neoliberal governance of refugee claims in Canada continued, reinforced and reproduced racial inequalities that aged long before the advent of neoliberalism. In other words, while neoliberalism is distinct in its totalizing primacy of economic thinking, it is not distinct from liberalism in the fact that it produces racialized and racializing effects through its mechanisms of governance. However, neoliberal governance produces these effects via novel and distinct mechanisms and logics. In the transition from liberalism to neoliberalism, the racialized assumption of irrationality of non-Europeans in classical liberal thought, as eloquently analyzed by Uday Mehta's (1990) discussion of John Locke, are replaced by racializing logics of economic viability. The racialized Other is no longer justifiably unequal due to her lack of capacity for rational thought, but is rendered unequal due to the economic unfeasibility of treating her as a true equal. Hence, by noting the continuation of racial difference in neoliberal governance, this paper traces how longstanding racialized effects are replicated through new and seemingly non-racial logics of economic rationality. In other words, this paper is both concerned with the continuation of liberal racial inequality in contemporary times, and the new mechanisms via which these old effects are delivered and institutionalized.

In the following sections I draw on organizational reports, review studies, and archival documents to explore the ways racialized formulations of economic migrants and neoliberal objectives of refugee governance have been interlocked. I will first provide a brief overview of refugee protection administration in contemporary Canada, particularly in relation to exclusion of economic migrants. I will then describe the 
bureaucratic struggles that marked Canada's early years of systematic refugee protection, along with some of the administrative solutions that were put to the task of resolving these struggles. In the final section, I will closely examine the racialized implications of these administrative procedures. I will show that these procedures were adaptive racialized operations that helped the refugee protection bureaucracy handle its challenging workload.

\section{Refugee protection in Neoliberal Canada}

In Canada, adjudication of in-land refugee claims is conducted by a politically independent and non-adversarial administrative tribunal called the Immigration and Refugee Board of Canada (IRB). Before the creation of the IRB in 1989, refugee claims were processed on an ad-hoc basis by an interdepartmental advisory committee that reported to the Immigration minister. This mode of refugee claim processing proved to be extremely slow, cumbersome, and ineffective: processing times ranged between two to five years (Plaut 1985), and a large and growing backlog of claims had begun to cause serious political problems (Dirks 1995).

Systematic refugee protection in Canada was to a large part an outcome of the Immigration Act 1976. This Act introduced the legal definition of refugee into Canadian immigration law. In doing so, the Act opened a new chapter in the history of refugee protection in Canada. With the refugee definition enshrined in immigration law, refugee claimants became entitled to unprecedented levels of legal protection; forms of protection that were previously matters of discretionary judgement were now codified legal entitlements. Legal entitlements, such as those to due process, ultimately necessitated a systematic and well-structured process for adjudicating refugee claims. Hence, with the passing of the Immigration Act 1976 the creation of the first systematic and specialized refugee claim processing bureaucracy was put into motion.

Introducing the legal definition of refugee to Canadian law was not the only contribution of the Immigration Act 1976. This Act marks a significant shift in Canadian immigration policy. The Act is perhaps best-known for removing race, ethnicity, and country of origin as legal criteria of exclusion from immigration to Canada. Instead, prospective immigrants were to be evaluated based on their skills, education, profession, and language proficiency, and in relation to the economic and occupational needs of Canada. The explicitly racial logics of immigration administration were now replaced with economic ones. These new logics created a way for making a racially neutral yet economically sound Canada. Canada was to be race-free yet prosperous and invested in its own prosperity.

The rising prominence of economic logics in Canadian immigration administration was not an isolated and exceptional phenomenon. Across the globe governments of advanced industrial countries were beginning to move towards prioritizing economic logics in their discourses and operations. With the full-blown rise of Thatcherism and Reaganism only a few years ahead, the global landscape was soon to see major changes in how governments were to operate, be structured, and perceive their functions. The New Public Management (Aucoin 1995, Ferlie et al. 1996, Lane 2000, Connell et al. 2009) was on its way to soon dramatically restructure the welfare state of the preceding decades. Neoliberal governance was setting in. Fiscal responsibility, cost-revenue 
analysis, and lean management were to become buzz words in government operations and discourses.

In this context, legislation of the refugee definition created a delicate dilemma. From a legal point of view, refugee protection is a humanitarian obligation detached from economic considerations or immigration policy goals. For instance, unlike immigrants, refugee claimants cannot be accepted or rejected based on their professional and educational skills, their compatibility with the Canadian labour market needs, or their ability to become self-supporting residents without prolonged public support. Refugee protection, moreover, is costly. In addition to requiring a specialized administrative bureaucracy, refugees and refugee claimants need social support services above and beyond what is offered to immigrants. As a result, the addition of the refugee definition to Canadian immigration law created an opening outside the normal streams of an economy-centred immigration framework, and potentially disturbed neoliberal goals and calculations. Hence, it created a problem that needed careful management.

It is perhaps a historical irony that systematic refugee protection in Canada came into being at a time poorly suited for this task. Legislation of the refugee definition and a number of other jurisprudential transformations had made the creation of a systematic and specialized refugee claim processing bureaucracy an unambiguous legal obligation for the Canadian state. Yet, with the rise of neoliberalism governments were under pressure to cut public spending and downsize their supposedly large and slow bureaucracies. Hence, creation of an entire department in charge of administering refugee protection was not easily compatible with the emerging neoliberal trends in public administration. In particular, a non-revenue generating, costly, and unpredictable operation for the good of non-tax paying, non-voting, non-citizens was not an easy fit with neoliberal logics of governance.

The need to work with unfaltering neoliberal logics and yet deliver systematized and procedurally sound refugee protection required state bureaucrats, politicians and policy makers to find ways to make refugee protection compatible with neoliberal goals of immigration administration. This meant, above all, setting boundaries on the humanitarian agenda of an economically self-preserving Canada. A tightly bounded vision of humanitarianism was widely promoted as the only practical and sustainable means of providing refugee protection. In this context, excluding economic migrants from refugee protection became integral to the operations of the new refugee protection bureaucracy.

Administrative discourses on refugee protection defined economic migrants as individuals whose migration to Canada was primarily motivated by economic reasons, yet they supposedly refused to submit to the time-consuming and merit-based immigration process set by the government of Canada. Following the common readings of the 1951 Convention relating to the Status Refugees and its 1967 Protocol, Canadian law considered economic hardship an insufficient ground for receiving refugee status. ${ }^{1}$

\footnotetext{
${ }^{1}$ The 1951 Convention and its 1967 Protocol recognize five grounds of persecution. These include race, nationality, political opinion, religion and membership in a particular social group. The Convention does not recognize class, economic status, or poverty as grounds for receiving refugee protection. Although the Convention definition has been challenged and expanded on grounds of gender and sexuality, economic status has never become a point of expansion in refugee jurisprudence.
} 
As migrants who were purportedly simply in search of better economic conditions, economic migrants were then considered not to be victims of persecution and lack a genuine claim to refugee protection

Of course, the omission of economic factors from the terms of the Convention was a direct result of the specific historical and political negotiations that underlay its drafting following the two World Wars and at the beginning of the Cold War. ${ }^{2}$ In other words, economic deprivation was not excluded from the grounds of the Convention because poor people do not suffer or are not exposed to persecution and systematic harm as a result of their lack of access to financial resources. Rather, socio-economic status was left out because the Convention was created for the purpose of a very narrow and specific geographical, historical, and (liberal) political agenda. Indeed, as Joan Fitzpatrick (1996) has noted, the generalized political, economic, and one may add environmental, devastation that produces mass displacement of non-Europeans was decidedly outside the intended scope of the 1951 Convention. Thus, the distinction between "real" refugees and economically motivated migrants was produced politically, rather than based on purely humanitarian concerns.

Indeed, economic migrants were cast out of refugee protection well before the advent of neoliberalism. In fact, the genealogy of the economic migrant as an informal figure of exclusion in the Canadian immigration discourse may be traced to well before the Immigration Act 1976. ${ }^{3}$ However, with legislation of the refugee category the economic migrant became an even more prominent figure, particularly in relation to and as a point of distinction from "real" refugees. Even pro-refugee advocates mobilized this figure to lend weight to "real" refugees and their legal entitlement to a proper and well-devised process of refugee status adjudication (see for instance Plaut 1985). In effect, the longstanding and politically produced distinction between "real" refugees and economic migrants both created a basis for and was reinforced by the neoliberal regime of refugee protection: neoliberal logics of governance quickly turned excluding economic migrants from refugee protection into a necessary component for providing proper protection to "real" refugees. Creating a systematic regime of refugee protection became possible partly because economic migrants were to be excluded from and by this very regime; neoliberal refugee protection relied on exclusion of economic migrants. The growing need for a centralized system of refugee claim adjudication and the tightly bounded vision of Canadian humanitarianism eventually led to the creation of the Immigration and Refugee Board of Canada in January 1989.

\footnotetext{
${ }^{2}$ For fuller discussions of the context of the creation of the 1951 Convention and its 1967 Protocol see Jackson (1991), Fitzpatrick (1996), and Keely (2001).

3 The genealogy of the economic migrant in the Canadian immigration discourse, law and policy deserves an independent study. This figure may be traced back at least a century. For instance, the historical work of Radhika Mongia (2007) allows uncovering key similarities between the contemporary figure of the economic migrant and the formulation of Indian British immigrants to Canada in the early 1900s. Like the contemporary economic migrant, Indian British immigrants were supposedly motivated by desires for economic gain, and yet failed to fit (or respect) the (racist) immigration policies set by the Canadian government. Furthermore, the two figures ultimately became "fair" targets of exclusion.
} 


\section{The Battle of Numbers: Bureaucracy against the economic migrant}

During the first year of the IRB's operation, senior IRB officials held a seminar with the Canadian press (Refugee Update Seminar for the Media 1989). These officials were fully aware of the contentious nature of their work, and wished to forge a strong and positive relation between the young IRB and the public.

In this seminar, Gordon Fairweather, the first chairperson of the IRB, offered an answer to an anticipated question:

You are entitled, of course, and will be asking us what are the challenges in the next couple of years. They are just one word, numbers. (Refugee Update Seminar for the Media 1989, 1)

Fairweather's representation of the IRB in a battle against numbers was not a frivolous remark. The early years of the IRB may accurately be described as a struggle against unfavourable odds and challenging numbers. Much public and political hope had been invested in the ability of the young IRB to solve Canada's in-land refugee protection problems and end the ongoing headache and dilemmas that refugee protection produced for politicians and the public. Not only was the IRB expected to keep up with the flow of incoming claims, it was also mandated to clear the large backlog of cases that the previous system had left behind. On the day the IRB began its operations, it inherited a backlog of 85,000 claims. Some of these had already been in the processing procedures for a number of years (IRB 1990).

Thus, the ability to stay in control of its daunting caseload and produce timely decisions was a key principle for the IRB since the earliest days of its operation. Efficient claim processing, both in terms of reducing processing times and optimizing the use of resources, was a great priority for IRB administrators. Set against its highly incompetent and inefficient predecessor, efficiency was already a marker of institutional worth and pride for the IRB. Efficient claim processing was also a material necessity for this young bureaucracy: as a government agency created in the stringent neoliberal culture of the late 1980s, the IRB had to work hard to prove that it was worth the resources allocated to it. It had to prove and publicize its success in order to survive political pressure and public criticism.

The political pressure on the IRB was exacerbated by its uncomfortable relationship with the Immigration Department. This contentious relationship largely stemmed from the fact that the IRB has been legislated to be completely independent from political authority. Of course, the IRB's political independence has been a great advantage to refugee claimants. Above all, this independence ensures that Canadian foreign policy cannot directly taint refugee decisions. However, the IRB's independence makes for a difficult and complicated relationship with the Immigration Department. From the perspective of the Immigration Minister the problem is understandable: while the poor performance of the IRB inevitably reflects on the Minister as the head figure on refugee and immigration matters, the Minister cannot freely intervene in the IRB's operations and shape them to her or his liking without raising accusations of political tampering. As a result, the IRB's independence has not always been received well by the Immigration Department officials or the Minister (see Hathaway 1993). For the IRB to survive inter-departmental tensions it has had to perform its best and demonstrate that 
it can in fact achieve challenging outcomes. In this context, increasing the efficiency of its claim processing became even more important to solidify the IRB's standing and worth as a federal agency.

The need to increase the efficiency of claim processing at the IRB has also been compounded by the unpredictability of the IRB's workload. As a bureaucracy that largely responds to consequences of overseas political crises, the IRB's caseload fluctuates based on factors that are completely beyond its control. Although the IRB has always tried to predict the upcoming patterns of displacement by monitoring international situations (see IRB 1991, 1992), it has never been able to fully predict or plan for the caseload that it will receive each year. In fact, the IRB often discovers the volume of its caseload as claims are filed. Therefore, maximizing efficiency has been important for managing the unpredictable and at times overwhelming workload at the IRB.

The desire to increase efficiency at the IRB has not been merely a matter of hypothetical concern. The need to increase the efficiency of IRB claim processing procedures very quickly became a necessity as the young IRB began operating. Within the first year of its operations the IRB found itself confronted with an incoming caseload that almost doubled the number it had been designed to process: while the IRB had the capacity to process about 1,500 claims per month, the last three months of 1989 produced caseloads that averaged about 3,000 claims (IRB 1990). This unexpected and overwhelming increase in the caseloads meant that by the end of 1989 8,000 claims had not even entered the first stage of the then two-staged adjudication procedures. The second stage of adjudications was also completely overwhelmed by the large number of incoming claims. Even more disturbingly, IRB officials correctly anticipated that the high rates of incoming claims were to continue into the following year.

The IRB administrators were monitoring the unexpected increases in the number of incoming claims with watchful eyes. They were keenly aware of the need to increase the efficiency of their procedures in order to manage the actual volume of their workload. They employed multiple and diverse strategies to increase efficiency. These strategies included increasing the number of hearing rooms in their busiest offices, enhancing hearing room booking practices, and exploring more expeditious methods of reviewing and adjudicating claims. Much attention, analysis, and creativity was devoted to running the IRB against the threat of accumulating backlogs. Practically every stage of the claim adjudication process came under close scrutiny and surveillance. Regular statistical reports were created to closely monitor the flow and movement of claims through all stages of the adjudication process; these reports were issued weekly, monthly, and quarterly, allowing analysis of IRB's performance, workload, and progress in short and longer terms. Increasing efficiency had become an unquestionable priority. It centrally shaped the IRB administrators' perceptions of their work and formed the culture and operations of the IRB for the years to come.

To cope with the considerable strain the increased workloads caused, the IRB had no choice but to request additional funds before the end of the first year of its operation. In 1989 the IRB's $\$ 42,297,000$ operating budget was increased by supplementary funds of $\$ 10,643,000$ (IRB 1990). The following year's $\$ 61,788,000$ budget was supplemented by $\$ 18,112,000$ (IRB 1991). These supplementary funds were highly appreciated, and were 
critical to increasing the IRB's output. These funds allowed the IRB to hire new adjudicating Members and open a new office in its busiest region, Toronto (IRB 1991). However, the supplementary funds did not increase the IRB's budget in proportion to the increase in its workload. As a result, the IRB had to fundamentally revise its procedures and expectations, and devise new and innovative plans for completing its workload with the allocated funds.

The IRB officials soon turned their attention to increasing the efficiency of claim processing through modifying the routine adjudication procedures that were already in place. These attempts led to the "expedited process" and its twin project "simplified inquiry process". These procedures were piloted in 1989 and further developed and heavily used in the following years to alleviate the pressure from the unexpectedly high caseloads (IRB 1990, 1991, 1992).

The expedited and simplified procedures were designed to quickly process claims that were considered to be evidently well-founded. Claims that were diverted to these procedures were selected based on the country of origin of claimants. Countries with supposedly unambiguous and well-established records of human rights violations that sent large numbers of refugees to Canada were placed on the expedited list. In the early years of the IRB's operations the expedited list included countries such as El Salvador, Iran, Lebanon, Somalia, and Sri Lanka (IRB 1990, 1991). Claimants from these countries already had extremely high acceptance rates, often ranging from $80 \%$ to over $90 \%$. The expedited and simplified procedures were effectively designed to quickly conclude the determination of claims that were likely to receive a positive decision in normal proceedings. It was believed that these cases were likely to be well-founded, and therefore could be decided more quickly and with fewer resources. For example, simplified and expedited procedures allowed positive decisions to be issued through informal meetings rather than formal two-Member ${ }^{4}$ hearings. Using procedural shortcuts and fewer resources to adjudicate these claims meant that the IRB could optimize the productivity of its existing resources and process a larger number of claims in a shorter period of time.

These early expedited procedures increased the IRB's efficiency through an in-built bias towards quick approval of evidently well-founded claims. However, the acceptanceinclined bias of expedited and simplified procedures was counterbalanced by a restrictionist administrative logic. This logic considered efficient refugee claim processing not only integral to proper refugee protection, but also an effective means of protecting the Canadian refugee system against "abuse" (see Plaut 1985). According to this logic, lengthy processing times produced incentives for abusers to jump immigration queues and buy themselves considerable time in Canada by filing a refugee claim. Hence, by reducing processing times not only would Canada offer timely protection to deserving refugees, it would also deter those claimants who intend to take advantage of Canada's humanitarian agenda.

Thus, increasing the efficiency of the IRB's operations carried the dual functions of timely protection of real refugees, and deterrence of fraudulent claimants (IRB 1990,

\footnotetext{
${ }^{4}$ At the time, refugee hearings were conducted by two adjudicating Members. Only one Member needed to accept a claim for the claimant to receive refugee status.
} 
1991, 1992). As the strain from the overwhelming caseloads grew, the deterrence function of the IRB became more prominent. Soon the IRB began to conceive deterrence as a necessary component for the success of its operations. The IRB officials began to call on the Immigration Department to more seriously commit to timely removal and deportation of rejected claimants (IRB 1991, 1992).

Of course, the IRB officials' interest in deterrence is understandable from an administrative point of view: deterrence reduced the workload of the IRB. Without effective deterrence, the caseloads were likely to grow beyond the IRB's capacity and make backlogs an inescapable reality. Accumulation of backlogs betrayed the high hopes invested in the IRB. It was imperative that the IRB moved through the claims in a timely fashion. Hence, the flow of incoming claims had to be kept at a manageable level. As a result, efficient claim processing and deterrence were tied to one another in a mutual bond: deterrence allowed fast and efficient refugee claim processing by reducing the workloads, while fast and efficient claim processing supposedly deterred the so-called fraudulent claimants. In the minds of the IRB officials, the Immigration Department's failure to conduct timely removals undermined the IRB's deterrence function as well as the overall and long-term success of its operations. ${ }^{5}$

With the growing pressure to increase the efficiency of claim processing at the IRB the deterrence function of the IRB was more heavily emphasized. Under pressure, the IRB became attached to and began to promote a rigid dichotomy between "real" refugees and "fraudulent" claimants. This polarized conception of refugee claimants allowed the IRB to assume harsh positions against fraudulent claimants, who were believed to include statistically large numbers of economic migrants. Despite occasional acknowledgement of the ways economic deprivation and poverty caused displacement (IRB 1990, 1993), the IRB officials mostly avoided sympathy with economic migrants and economically deprived groups of claimants.

Categorizing economic migrants as fraudulent and excludable provided new administrative avenues for managing the IRB's workload. Economic migrants became key and strategic targets for the IRB's deterrence measures. Ghettoizing and excluding these migrants became a central strategy for driving the number of incoming claims down. To ensure the sustainability and survival of the young agency, the IRB administrators had to reject, remove, and deter economic migrants. But first, these migrants needed to be located.

\section{Locating economic migrants: Racialization and bureaucratic efficiency}

As noted earlier, economic migrants became a key administrative tool in managing the unpredictable and heavy workload of the young IRB. Widely conceived as fraudulent, opportunistic and unworthy of protection, rejecting economic migrants was considered fair, necessary and consequential. Not only did rejecting these claimants showcase rigorous decision making at the IRB, it was also an integral part of a systematic strategy of deterrence that spanned across the multi-actor refugee protection system. Officials at the IRB as well as the Immigration Department firmly believed that rejecting economic

\footnotetext{
${ }^{5}$ At the time, the IRB officials strongly suspected that the Immigration Department intentionally stalled its immigration control functions in order to sabotage the effectiveness of the IRB's work (Hathaway 1993).
} 
migrants sent a clear message to those who intended to take advantage of the Canadian refugee system (Letter from Nick Mulder to Paul Tellier 1990). Rejecting economic migrants became equivalent to deterring abuse.

Of course, rejecting and deterring economic migrants required locating them within the large pool of claimants. Importantly, economic migrants needed to be identified efficiently, systematically, and quickly. This meant that adopting a strictly legal method of decision making based on close examination of the content of each claim was not a plausible strategy. Effective deterrence required shorthand methods that helped locate large numbers of economic migrants quickly and with few resources.

Claimants' countries of origins provided this shorthand method. Firstly, claimants' country of origin was recorded as a basic background information in their applications. As such, this information was available and easily accessible. Secondly, the existing documentation packages and widely held perceptions about conditions of life in various countries made countries of origins an easy tool for roughly locating economic migrants. In accordance with the class-based biases of refugee law and the 1951 Convention, ${ }^{6}$ the IRB administrators and decision makers largely believed that claimants from countries with well-documented political and civil crises or with non-liberal and authoritarian regimes were more likely to be genuine refugees. Conversely, poor countries that supposedly did not suffer from serious human rights violations were considered to be likely producers of economic migrants.

This methods of locating economic migrants was, of course, rooted in the inherent failure of refugee law in acknowledging socio-economic deprivation as a legitimate source of displacement. However, the practice of locating economic migrants through their countries of origins was far from a neutral and objective application of (deficient) legal provisions to country conditions. Above all, this method of locating economic migrants relied on racialized formulations of certain national groups that featured prominently in Canada's refugee protection regime or the Canadian racial imaginary. These racialized formulations provided quick and easy ways for identifying groups of economic migrants, despite and against the legal requirement of individual and merit-based assessment of claims. By stealthily circumventing the legal rigours of individual and equal treatment of each claim, nation-based methods of locating economic migrants reproduced forms of racialized knowledge that allowed certain groups to be readily excluded from refugee protection. In effect, the need to locate and reject economic migrants quickly and efficiently soon devolved to racialized and racializing bureaucratic methods. Under the intense pressures imposed by neoliberal governance, racialization became an administrative tool in handling the workload of the IRB.

The racialized knowledges that were cultivated throughout the refugee protection bureaucracy at times reproduced long-standing racialized imaginaries. In doing so, these knowledges continued the legacy of racialized exclusion despite the removal of race as a category of exclusion from Canadian immigration law: some of the groups that

\footnotetext{
${ }^{6}$ Refugee law defines prosecution in ways that largely limits it to individualized experiences of political and civil violence. Conversely, economic and generalized violence is excluded from the legal definition of persecution and, consequently, refugee protection.
} 
had long been barred from immigration to Canada due to their racial undesirability now became excludable from refugee protection as economic migrants.

The first countries that were considered likely producers of economic migrants were Jamaica, Trinidad and Portugal. Historically, nationals of these countries, particularly those from Jamaica and Trinidad, had not been considered racially desirable immigrants (Pineo 1977, Satzewich 1989, Henry 1994). The young IRB followed the established racialized conceptions about nationals of these countries and viewed them to be in need of management and deterrence.

IRB administrators believed that the high number of claims from these countries, especially Trinidad and Portugal, had contributed to the collapse of the previous system of refugee protection in Canada (Refugee Update Seminar for the Media 1989, IRB 1990). As a result, they believed rejecting and deterring claimants from these countries was necessary if the IRB was to avoid the tragic fate of its predecessor. Claims from these countries were widely believed to be without legitimate basis. This belief was so deeply engrained throughout the refugee protection regime that administrators simply thought that efficient refugee protection would automatically reduce the number of claims from these countries (IRB 1990). In other words, reducing the number of claims from these countries became an administrative goal as well as a marker of organizational success. It was in this vein that at the end of its first year of operation the IRB reported an acceptance rate of $0 \%$ for claimants from Jamaica and Trinidad 7 (IRB 1990).

Claims from Jamaica and Trinidad may well have been largely incompatible with the narrow provisions of refugee law. However, as I will show throughout this section, the categorical rejection and intense bureaucratic focus on these claims preceded individual assessment of their substance. Actors across the Canadian refugee protection regime intended to deter, reject and exclude these claimants, as they were already believed to be fraudulent and lack credibility. Hence, Jamaican and Trinidadian claimants were systematically exposed to differential bureaucratic treatment because of the (racialized) categorization of their countries as producers of economic migrants. In other words, the neoliberal governance of refugee claims utilized group-based and racialized methods of exclusion that went far beyond the class-based biases of refugee law.

Reporting the $0 \%$ acceptance rates of Jamaican and Trinidadian claimants achieved two purposes for the IRB administrators. First, by reporting these rates the IRB demonstrated its commitment to deterring economic migrants. Secondly, these rates helped the IRB navigate a complex and emerging politics that concerned the overall acceptance rates of refugee status adjudications. The first year of the IRB's work had produced an

\footnotetext{
${ }^{7}$ Of course, refugee decisions are made by independent adjudicators who cannot be directly controlled by IRB administrators. The $0 \%$ acceptance rates of claimants from Jamaica and Trinidad in 1989 perhaps points to adjudicators' strong disbelief of these claimants. Although these $0 \%$ acceptance rates cannot be directly attributed to the IRB administrators, the fact that these rates were highlighted in the annual report is illustrative of the IRB administrators' negative conception of these countries.
} 
exceptionally high acceptance rate of $76 \% .{ }^{8}$ This rate was considerably higher than the approximately 30\% acceptance rate in the previous system (IRB 1990). Clearly anticipating questions regarding this rate, the IRB officials offered an explanation for their high acceptance rates in their first annual report. Notably, they suggested that the high acceptance rate demonstrates the IRB's success in deterring fraudulent claimants (IRB 1990). They argued that unlike what had transpired in the previous system, the vast majority of IRB claimants originated from countries with well-documented political and civil crises. Hence, given its vastly legitimate pool of claimants, the IRB acceptance rate was understandably high.

Thus, the IRB administrators reported the $0 \%$ acceptance rates of Jamaican and Trinidadian claimants to demonstrate the competence, rigor and prudence of their organization. By juxtaposing these rates against the exceptionally high acceptance rates of claimants from countries with supposedly real human rights issues, the IRB officials defended the integrity of their organization. Through these rates they suggested that the IRB was not simply too lenient and trusting of claimants. Rather, it was well-prepared to unequivocally reject and deter unfounded claims while extending its protection to genuine refugees only ${ }^{9}$. Hence, in its struggle to secure legitimacy and respect as a young bureaucracy, the IRB turned Jamaican and Trinidadian claimants into discursive tools that categorically exemplified the excludable economic migrant.

Exclusion and deterrence of nationals of counties such as Trinidad and Jamaica soon became an actual indicator of the IRB's performance. This indicator was used by and beyond the IRB. For example, in his letter to the Clerk of the Privy Council and Secretary to the Cabinet in January 1990, the Associated Deputy Minister of the Immigration Department expressed his approval of the IRB's performance by directly equating successful deterrence of unfounded claims with elimination of claims from countries such as Trinidad and Portugal:

[The IRB] reduced significantly the number of manifestly unfounded claims; that is, we have reduced to a trickle individuals (such as Turks, Portuguese, Trinidadians, etc.) who are not refugees but who used to arrive in large numbers under the old system. (Letter from Nick Mulder to Paul Tellier 1990, 1)

Importantly, institutionalized scapegoating of countries that were supposedly likely producers of economic migrants was underpinned by practical strategies at the adjudication level. A UNHCR visiting consultant to the IRB's documentation centre in August 1989 reported concern about the ways IRB adjudicators approached and used

\footnotetext{
${ }^{8}$ Acceptance rates in early years of the IRB may be reported variously. For instance, acceptance rates in 1989 may be reported as $84 \%$ or $76 \%$. This discrepancy is due to the substantial procedural changes made to claim adjudication over the years. In the earlier years, the IRB followed a two-staged adjudication process. The first stage was conducted by officials from the IRB and the Immigration Department and focused on determining refugee eligibility using a low threshold test. This stage was relatively quick and often produced very high acceptance rates (in the 90\%). Claims approved at the first stage were then referred to the second stage. The second stage involved a full hearing with two IRB Members and was much more timeconsuming and rigorous. In 1989, the second stage produced an acceptance of $84 \%$, while the two stages together produced an acceptance rate of $76 \%$. Since the second stage is more procedurally comparable to the current single-stage system of adjudication, the acceptance rates from the second stage are sometimes used to compare acceptance rates across time and in recent years.

9 This argument was not considered sufficiently convincing by the Immigration Department, and the IRB soon came under great pressure to reduce its acceptance rates (Letter from Nick Mulder to Paul Tellier 1990).
} 
documentations on country conditions. The consultant suggested that adjudicating Members commonly treated reports on country conditions as clear and straightforward indicators of the credibility or incredibility of refugee claims (UNHCR Consultant's Visit 1989). Instead of using country reports as the broader background context for analyzing the unique circumstances of each claimant, as per the requirement of refugee law, Members looked to country documentations for directions on whether to decide for or against a claim. As a result, country conditions weighed heavily in Members' decisions, and acceptance rates were highly polarized based on countries of origin. In effect, IRB adjudicators commonly perceived all or the vast majority of claimants from some countries as genuine refugees while claimants from a number of other countries were largely considered to be economic migrants; refugee status was practically adjudicated based on the country origin rather than the content of individual claims. Although highly problematic from a legal standpoint, the polarized perceptions of different countries helped simplify the truly difficult task of credibility assessment. Under the heavy pressures of growing caseloads, adjudicating Members perhaps felt the need to resort to using country reports as relatively reliable shortcuts for making quick decisions. These practices, nonetheless, produced polarized effects that systematically disadvantaged nationals of countries such as Jamaica and Trinidad.

Moreover, exclusionary practices against countries such as Trinidad and Jamaica ran far beyond the IRB. Trinidadian and Jamaican claimants were treated with strong disbelief throughout the Immigration Department. The prevalent disbelief against these claimants is evident in Ministerial concession rates. In the non-adversarial model of refugee status adjudication in Canada, the Minister remains a party in refugee decisions. This means that the Minister has the right to contest refugee decision s/he finds problematic. By contesting decisions the Minister appeals the adjudication outcome and has a chance to provide reasoning and documentation against the decision. Ministers often only contest a small portion of adjudicated claims. In the early years of the IRB, representatives of the Minister had the right to contest positive evaluations of claims' credibility at the first stage of the adjudication process. The Minister's decision not to contest a positive initial evaluation was called a concession. Concessions allowed claims to swiftly move to the second stage of adjudications for further examination.

Ministerial concession rates in the early years of the IRB's operations suggest that the Immigration Department officials and the Minister shared the perception that Trinidadian and Jamaican claimants were unlikely to be genuine refugees. Not only did these claimants have very low acceptance rates at the IRB, the concession rates of their claims were also very low. In the rare instances when a positive initial evaluation was issued on claims from Jamaica and Trinidad, the Minister was considerably less likely to concede. In 1990 no cases from Trinidad and only one positive initial decision from Jamaica was conceded. These numbers contrasted with the $95 \%$ concession rates of claimants from countries that were considered legitimate sources of refugees (CRDD Statistical Report-December 1990-January 1991). This means that odds were largely stacked against claimants from Jamaica and Trinidad; multiple departments worked to reject and exclude these claimants at various stages of the adjudication process.

At times, scapegoating of economic migrants took interesting regional patterns that corresponded with local histories of race relations. The regional offices of the IRB often 
produced highly disparate acceptance rates. For instance, in 1990, acceptance rates of refugee claims were $81 \%$ and $86 \%$ in Ontario and the Prairies respectively, and only $55 \%$ in British Columbia. The considerably lower acceptance rates of the BC office was explicitly attributed to the fact that a high proportion of claimants in this office came from China (CRDD Statistical Report-December 1990-January 1991). As may be expected given the long history of anti-Chinese exclusion and racism in BC (Morton 1974, Wynne 1978, Stanley 2011), Chinese claimants were subject to higher rates of rejection in this region. For example, in 1990 decisions made at full hearings of Chinese claimants in Quebec produced 277 positive and 241 negative outcomes, a relative acceptance rate of 53\%. ${ }^{10}$ However, full hearings of Chinese claimants in B.C. produced 81 positive and 167 negative decisions, a considerably lower relative rate of $33 \%$. Nationally, 485 Chinese claimants received a positive decision at full hearings, while 600 claimants were declined, constituting a relative acceptance rate of $45 \%$ (Statistical summary 1991). These disparities in acceptance rates of Chinese claimants suggest that scapegoating certain countries as countries of economic migrants was not exclusively a national practice. Regional offices also developed their own excludable national groupings and complemented the national blacklist of countries of economic migrants with their own local and racialized scapegoats. The regional scapegoats reflected local histories of race relations as well as the administrative needs of the offices.

Of course, Jamaica, Trinidad, and China were not the only countries of concern for the IRB. The IRB closely monitored the rates of incoming claims from all countries, and paid particular attention to the countries that either sent relatively large numbers of claimants to Canada, or whose number of claimants were on the rise.

Due to the dissolution of the Soviet Union, in early 1990s the number of refugee claimants from Eastern Europe was quickly increasing. This made Eastern European countries, particularly Czechoslovakia and Poland, a focus of deterrence measures. Although the IRB positively characterized the fall of the Soviet Union as "democratization" (IRB 1991, 13), it remained somewhat sympathetic to the ways political and economic instability and ethnic and nationalist tensions created displacement in Eastern Europe. Nonetheless, the arrival of large numbers of Eastern European refugee claimants in Gander, Newfoundland, pushed the caseload of the IRB to unprecedented highs: the IRB received 4,200 claims in January, 3,300 claims in February, and 3,800 claims in March 1990 (CRDD Statistical Report-First Quarter 1990). The hike in the number of Eastern European claimants, informally titled "the Gander situation", became a serious concern for the IRB and the Immigration Department. Administrators believed that controlling the number of Eastern European claimants was key to keeping the IRB's workload at a reasonable and manageable level. As a result, the IRB and the Immigration Department began to implement comprehensive and punishing strategies to deter Eastern Europeans from accessing the Canadian refugee protection regime.

Firstly, Eastern European claimants, particularly those from Czechoslovakia and Poland, began to be rejected at higher rates in both stages of the adjudication process at the IRB.

\footnotetext{
10 The numbers reported in this discussion reflect the numbers of claims decided at full hearings, and hence exclude the number of claims rejected at the initial stage of adjudication (to be discussed later) as well as abandoned and withdrawn claims.
} 
These claimants began to be referred to the full hearing stage at lower rates. For instance, the referral rate of Polish claimants dropped from 83\% in 1989 to $64 \%$ in the first half of 1990. Czechoslovakian claimants' referral rates went down from $98 \%$ to $58 \%$ in the same period (Review of convention refugee determination division activities 1990). The acceptance rates of these claimants at the full hearing stage also dropped sharply: Polish claimants were accepted at a rate of $18 \%$ in the first half of 1990, starkly lower than their 1989 73\% acceptance rate. Claimants from Czechoslovakia saw a sharp drop from $75 \%$ to $12 \%$ in the same period (ibid.). All in all, the overall acceptance rates of claimants from Czechoslovakia dropped from 74\% in 1989 to only 11\% in 1990, and Polish claimants' rates were dropped from $51 \%$ in 1989 to $12 \%$ (IRB 1991).

Secondly, the Immigration Department began to challenge larger numbers of Eastern European claims that were positively evaluated by IRB adjudicators. For instance, while positive initial decisions on claims from countries such as Sri Lanka, Somalia and Iran were almost never contested, in the first quarter of 1990 positive decisions of Czechoslovakian and Polish claimants at the initial stage were contested at rates of $41 \%$ and 64\% respectively (CRCC Statistical Report-First Quarter 1990). More importantly, contesting claims from these countries were likely to reverse the positive initial decision: in the first quarter of 1990s 75\% of contested claims from Czechoslovakia and half of the contested claims of Polish claimants reversed the positive initial decision (ibid.). Hence, it soon became considerably harder for claimants from these countries to receive refugee status in Canada. These unfavourable conditions perhaps contributed to high withdrawal rates of Eastern European claimants, particularly those from Poland.

Thirdly, the Immigration Department began to impose visa restrictions against Eastern Europeans who wished to enter Canada. These visa restrictions proved to be effective tools for reducing the number of Eastern Europeans who made refugee claims in the Canadian refugee protection regime. By the middle of 1990 the number of Eastern Europeans who filed refugee claims in Canada was considerably lower. This helped substantially reduce the overall caseload of the IRB (Review of Convention Refugee Determination Division Activities 1990). The successful deterrence of Eastern European claimants meant that by March 1991 the IRB was seeing noticeable drops in the number of its incoming claims (CRCC Statistical Report-March 1991). ${ }^{11}$

The treatment of Eastern European claimants in this period is of course highly problematic in its own right. Nonetheless, close analysis of these claimants' treatment compared to those of Caribbean origins reveals a racialized pattern of exclusion. Countries that had long and racialized histories of exclusion from Canada, such as Trinidad and Jamaica, were overwhelmingly filtered out of the adjudication process at the initial stage: in the first half of 1990 \% of Trinidadian and $17 \%$ of Jamaican claimants

\footnotetext{
11 Eligibility of claimants for refugee status is determined based on factors such as claimants' history of criminality, past claims for refugee status in Canada, and access to citizenships or permanent residencies in third safe countries. These factors determine whether a claimant is eligible to be considered for refugee status. Credibility assessment requires examining the content of a claimants' case to decide whether they are in need of refugee protection. Credibility assessments at the initial stage involved basic evaluations of whether the claim has a basis that fit with the provisions of refugee law. Since comprehensive credibility assessment requires serious engagement with the content of claims, credibility decisions were largely left to the discretion of the IRB Members in full hearings, where adjudicators supposedly had more time and resources to establish credibility issues.
} 
were referred from the initial stage to full hearings (ibid.). This sharply contrasted with the overall referral rates of $95 \%$ in this period (ibid.). And although referral rates of Czechoslovakia and Poland had also received a hit, they continued to be on considerably higher levels at $58 \%$ and $64 \%$ respectively (ibid.).

The fact that large portions of claimants from Jamaica and Trinidad were rejected at the initial stage of the adjudication reflects the deeply held perceptions of these claimants as fraudulent and motivated by economic aspirations. Generally, not many claimants were rejected at the initial stage. The initial stage was largely reserved for assessments of eligibility and basic credibility of claims using a low threshold (IRB 1990). This stage was designed to screen out glaringly obvious non-refugees. Rejecting claimants at the initial stage removed them from the adjudication process without granting them a chance to represent their cases in a full hearing. This made it an extreme yet quick and inexpensive method of moving supposedly evidently unfounded claims out of the system.

The extremely low referral rates of Jamaican and Trinidadian claimants, hence, suggest that rejecting these claimants was not considered a contentious or complicated matter. These claimants were simply considered not to be genuinely in need of protection. In fact, in the initial assessments most of Jamaican and Trinidadian claimants were rejected based on the credibility of their claims rather than their ineligibility to receive refugee status: in 1990, out of the 59 Jamaican claims concluded at the initial stage, only 1 was rejected based on ineligibility; conversely, 42 eligible claims were rejected for supposedly lacking a credible basis without being granted a full hearing (Statistical summary 1991). Similarly, only three of the 51 concluded initial claims by Trinidadian claimants were found to be ineligible; 37 eligible claimants were rejected based on credibility issues (ibid.). As a result, very few or no Jamaican and Trinidadian claimants were referred to the full hearing stage for further assessment of their claims.

By regularly rejecting claims from Jamaica and Trinidad based on credibility at the initial stage, the IRB and Immigration Department decision makers implicitly ruled these claims to be undeserving of full adjudicative attention and resources. These practices exposed Jamaican and Trinidadian claimants to punishing and differential bureaucratic treatments. Moreover, the high rejection rates of these claims at the initial stage were often presented as proof of the success of the initial stage in performing its function: the initial stage was purportedly capably detecting and rejecting evidently unfounded claims. A review of the IRB refugee adjudication procedures in July 1990 reported the low referral rates of Jamaican and Trinidadian claimants and concluded:

So, the initial hearing stage is continuing to perform its basic function of culling out claims from countries that are clearly not sources of convention refugees and ensuring that claimants from countries that are known to be in upheaval get sent on for a full hearing. (Review of Convention Refugee Determination Division Activities 1990, 8)

While claimants from Jamaica and Trinidad were largely and swiftly rejected at the initial stage, claimants that had more recently joined the ranks of economic migrants, such as Czechoslovakian and Polish claimants, were primarily rejected at the second stage of the adjudication process. Although these national groups were not considered the most ideal sources of immigrants (Pineo 1977), they did not share the same long and racialized history of exclusion as countries such as Jamaica and Trinidad. In fact, at the outset of mass migrations from Eastern Europe the IRB noted Canada's long-standing 
tradition of providing refuge to displaced people of Europe and acknowledged the existence of large communities of Eastern Europeans in Canada (IRB 1991). In effect, the IRB had initially expected to receive these claimants with open arms.

The differential racial positioning of claimants from Eastern Europe compared to those from the Caribbean informed the different methods of exclusion that were afforded to these two groups. Although both classes of claimants were eventually scapegoated and excluded in large numbers, they were nonetheless exposed to differential bureaucratic treatments that were, above all, based on their (racialized) nationalities. While Eastern European claimants were much more likely to be granted a full hearing, nationals of Jamaica and Trinidad were largely rejected without ever being given a chance to fully present their claims. Evidently, more resources and attention were devoted to assessing and rejecting Eastern European claims. Non-white Caribbean scapegoats, on the other hand, were more readily and cheaply rejected.

\section{Conclusion}

In this paper I argued that legislation of the refugee category and creation of a systematic process of refugee protection in Canada has relied on exclusion of claimants who have come to bear the label of economic migrant. As I have shown, systematic refugee protection in Canada came into being at a time when neoliberal logics of governance began to heavily dominate public administration and government operations. In order to make itself viable to the overpowering force of neoliberalism, the new Canadian refugee protection bureaucracy had no choice but to continually strive for increased efficiency. The unfavourable circumstances that marked the early operations of the young IRB, including overwhelming workloads and interdepartmental tensions, made deterrence and exclusion of economic migrants an unquestionable necessity.

Furthermore, I argued that the exclusion of economic migrants from refugee protection relied on racialized knowledges about certain bodies and populations. The institutional procedures that worked to exclude economic migrants inherited, drew upon, and reproduced existing racialized formulations. These formulations provided efficient and short-hand methods for locating economic migrants within the large pool of claimants. In other words, racialization of the economic migrant became an administrative tool that helped the young bureaucracy manage its challenging workload. Neoliberal governance of refugee protection, thus, was a racialized and racializing project.

\section{References}

Andreas, P., 1996. US-Mexico: Open Markets, Closed Border. Foreign Policy, 103, 51-69.

Aucoin, P., 1995. The New Public Management: Canada in Comparative Perspective. Montreal: Institute for Research on Public Policy.

Brown, W., 2015. Undoing the Demos: Neoliberalism's Stealth Revolution. Brooklyn, NY: Zone Books.

Connell, R., Fawcett, B., and Meagher, G., 2009. Neoliberalism, new public management and the human service professions: Introduction to the special issue. Journal of Sociology [online], 45(4), 331-338. Available from: https://doi.org/10.1177/1440783309346472 [Accessed 5 March 2019]. 
Davis, D.A., 2007. Narrating the mute: Racializing and racism in a neoliberal moment. Souls [online], 9(4), 346-360. Available from: https://doi.org/10.1080/10999940701703810 [Accessed 5 March 2019].

Dirks, G.E., 1995. Controversy and Complexity: Canadian Immigration Policy During the 1980s. Montreal: McGill-Queen's University Press.

Enck-Wanzer, D., 2011. Barack Obama, the Tea Party, and the Threat of Race: On racial neoliberalism and born-again racism. Communication, Culture $\mathcal{E}$ Critique [online], 4(1), 23-30. Available from: https://doi.org/10.1111/j.1753-9137.2010.01090.x [Accessed 5 March 2019].

Ferlie, E., et al.,1996. The New Public Management in Action. Oxford University Press.

Fitzpatrick, J., 1996. Revitalizing the 1951 Refugee Convention. Harvard Human Rights Journal, 9, 229-254.

Giroux, H., 2008. Against the Terror of Neoliberalism: Politics Beyond the Age of Greed. London: Paradigm.

Goldberg, D.T., 2009. The Threat of Race: Reflections on Racial Neoliberalism. Malden: Wiley-Blackwell.

Hathaway, J.C., 1993. Rebuilding trust: Report of the review of fundamental justice in information gathering and dissemination at the Immigration and Refugee Board of Canada. Ottawa: Immigration and Refugee Board.

Henry, F., 1994. The Caribbean Diaspora in Toronto: Learning to Live with Racism. University of Toronto Press.

Immigration and Refugee Board, 1990. Annual Report for the year ending December 31, 1989. Ottawa: Immigration and Refugee Board.

Immigration and Refugee Board, 1991. Annual Report for the year ending December 31, 1990. Ottawa: Immigration and Refugee Board.

Immigration and Refugee Board, 1992. Annual Report for the year ending December 31, 1991. Ottawa: Immigration and Refugee Board.

Immigration and Refugee Board, 1993. Annual Report for the year ending December 31, 1992. Ottawa: Immigration and Refugee Board.

Jackson, I.C., 1991. The 1951 Convention Relating to the Status of Refugees: A Universal Basis for Protection. International Journal of Refugee Law [online], 3(3), 403-413. Available from: https://doi.org/10.1093/ijrl/3.3.403 [Accessed 5 March 2019].

Keely, C.B., 2001. The International Refugee Regime(s): The End of the Cold War Matters. International Migration Review [online], 35(1), 303-314. Available from: https://doi.org/10.1111\%2Fj.1747-7379.2001.tb00016.x [Accessed 5 March 2019].

Lane, J.E., 2000. New Public Management: An Introduction. London / New York: Routledge. 
Mehta, U., 1990. Liberal Strategies of Exclusion. Politics and Society [online], 18 (4), 427454. Available from: https://doi.org/10.1177/003232929001800402 [Accessed 5 March 2019].

Melamed, J., 2006. The spirit of neoliberalism: From racial liberalism to neoliberal multiculturalism. Social Text [online], 24(4(89)), 1-24. Available from: https://doi.org/10.1215/01642472-2006-009 [Accessed 5 March 2019].

Mongia, R.V., 2007. Historicizing state sovereignty: Inequality and the form of equivalence. Comparative Studies in Society and History [online], 49(2), 384-411. Available from: https://doi.org/10.1017/S0010417507000539 [Accessed 5 March 2019].

Morton, J., 1974. In the Sea of Sterile Mountains: The Chinese in British Columbia. Vancouver: J.J. Douglas.

Omi, M., and Winant, H., 1994. Racial Formation in the United States: From the 1960s to the 1990s. New York: Routledge.

Ong, A., 2003. Buddha is Hiding: Refugees, Citizenship, the New America. Berkeley: University of California Press.

Pineo, P.C, 1977. The Social Standing of Ethnic and Racial Groupings. Canadian Review of Sociology and Anthropology [online], 14(2), 147-57. Available from: https://doi.org/10.1111/j.1755-618X.1977.tb00338.x [Accessed 5 March 2019].

Plaut, W.G., 1985. Refugee determination in Canada: Proposals for a new system: A report to the Honourable Flora MacDonald, Minister of Employment and Immigration. Ottawa: Minister of Supply and Services Canada.

Roberts, D.J., and Mahtani, M., 2010. Neoliberalizing Race, Racing Neoliberalism: Placing "Race" in Neoliberal Disocurses. Antipode [online], 42(2), 248-257. Available from: https://doi.org/10.1111/j.1467-8330.2009.00747.x [Accessed 5 March 2019].

Satzewich, V., 1989. Racism and Canadian immigration policy: The government's view of Caribbean migration, 1962-1966. Canadian Ethnic Studies, 21(1), 77-97.

Sharma, N., 2001. On being not Canadian: The social organization of "migrant workers" in Canada. Canadian Review of Sociology [online], 38(4), 415-439. Available from: https://doi.org/10.1111/j.1755-618X.2001.tb00980.x [Accessed 5 March 2019].

Soss, J., Fording, R.C., and Schram, S.F., 2011. Disciplining the Poor: Neoliberal Paternalism and the Persistent Power of Race. University of Chicago Press.

Stanley, T.J., 2011. Contesting White Supremacy: School Segregation, Anti-Racism, and the Making of Chinese Canadians. Vancouver: UBC Press.

The Globe and Mail, 1978. New immigration act tightens entry rules. The Globe and Mail, 11 April, 8.

Wynne, R.E., 1978. Reaction to the Chinese in the Pacific Northwest and British Columbia, 1850-1910. New York: Arno Press. 


\section{Archival Material References}

CRDD Statistical Report-December 1990, 30 January 1991, RG 76 B-1, Box 1993/1994, File 8620-19, Volume 003, Refugee and Displaced Persons-General-Immigration and Refugee Board, Department of Employment and Immigration fonds, Library and Archives Canada, Ottawa, Canada.

CRDD Statistical Report-First Quarter 1990, 24 April 1990, RG 76 B-1, Box 1993/1994, File 8620-19, Volume 003, Refugee and Displaced Persons-General-Immigration and Refugee Board, Department of Employment and Immigration fonds, Library and Archives Canada, Ottawa, Canada.

Letter from Nick Mulder to Paul Tellier, 8 January 1990, RG 76 B-1, Box 1993/1994, File 8620-19, Volume 003, Refugee and Displaced Persons- General-Immigration and Refugee Board, Department of Employment and Immigration fonds, Library and Archives Canada, Ottawa, Canada.

Refugee update seminar for the media, 1989, RG 76 B-1, Box 1993/1994, File 8620-19, Volume 002, Refugee and Displaced Persons- General-Immigration and Refugee Board, Department of Employment and Immigration fonds, Library and Archives Canada, Ottawa, Canada.

Review of convention refugee determination division activities, July 1990, RG 76 B-1, Box 1993/1994, File 8620-19, Volume 003, Refugee and Displaced PersonsGeneral-Immigration and Refugee Board, Department of Employment and Immigration fonds, Library and Archives Canada, Ottawa, Canada.

Statistical Summary, 29 January 1991, RG 76 B-1, Box 1993/1994, File 8620-19, Volume 003, Refugee and Displaced Persons-General-Immigration and Refugee Board, Department of Employment and Immigration fonds, Library and Archives Canada, Ottawa, Canada

UNHCR consultant's visit, 22 August 1989, RG 76 B-1, Box 1993/1994, File 8620-19, Volume 002, Refugee and Displaced Persons-General-Immigration and Refugee Board, Department of Employment and Immigration fonds, Library and Archives Canada, Ottawa, Canada. 